\title{
SELEKTIVITAS KISI-KISI JUVENILE AND TRASH EXCLUDER DEVICES PADA ALAT TANGKAP TRAWL MINI DI PERAIRAN UTARA JAWA
}

\author{
Hufiadi1), Mahiswara1), dan Erfind Nurdin') \\ 1) Peneliti pada Balai Riset Perikanan Laut, Muara Baru-Jakarta \\ Teregristrasi I tanggal: 4 Mei 2006; Diterima setelah perbaikan tanggal: 12 Maret 2008; \\ Disetujui terbit tanggal: 20 Oktober 2008
}

\begin{abstract}
ABSTRAK
Perikanan trawl mini dasar yang berkembang merupakan alat tangkap yang efektif dalam memanfaatkan sumber daya ikan demersal. Permasalahan utama pada perikanan ini banyak jumlah hasil tangkap sampingan berukuran kecil yang belum layak tangkap. Penelitian observasi dan uji coba operasi penangkapan untuk mengetahui tipe perikanan trawl mini dan upaya untuk mengurangi tangkapan ikan muda telah dilakukan di perairan utara Jawa. Uji coba operasi penangkapan dilakukan melalui penggunaan perangkat juvenile and trash excluder devices pada alat tangkap trawl mini. Perangkat juvenile and trash excluder devices yang digunakan dibedakan pada ukuran jarak antar kisi-kisi 10,0; 17,5; dan 25,4 mm. Analisis selektivitas kisi menggunakan model kurva logistik dengan bantuan solver pada microsoft excel. Hasil penelitian menunjukkan penggunaan juvenile and trash excluder devices pada trawl mini dapat meloloskan ikan muda atau ukuran kecil berkisar 2,42 sampai dengan 63,45\%. Juvenile and trash excluder devices dengan ukuran kisi-kisi 17,5 mm memiliki tingkat pelolosan ikan-ikan muda atau rucah paling efektif pada tingkat seleksi $50 \%\left(\mathrm{FL}_{50 \%}\right)$.
\end{abstract}

KATAKUNCI: juvenile and trash excluder devices, trawl mini, kisi-kisi, rasio pelolosan, selektivitas

ABSTRACT: Selectivity of juvenile and trash excluder devices on mini trawl in northern Java waters. By: Hufiadi, Mahiswara, and Erfind Nurdin

Mini bottom trawls are effective fishing gear to exploit demersal fish resources. However, the gears operation have serious problem on amount of bycatch caught especially for juvenile and trash fish. Observation and experimental fishing were conducted to know type of mini bottom trawls in northern Java waters and to reduce catches of juvenile and trash fish. Juvenile and trash excluder devices are a selective device that equipped on mini trawl in the experimental fishing with different space bar of the juvenile and trash excluder devices (i.e.10.0; 17.5; and $25.4 \mathrm{~mm}$ ). The selectivity analysis of logistic curve by using solver on microsoft excel was applied. The results show that juvenile and trash excluder devices could reduced catches of juvenile and trash fish about 2.42 to $63.45 \%$. Juvenile and trash excluder devices with $17.5 \mathrm{~mm}$ of the space bar was better for juvenile selection length of $50 \%\left(F L_{50 \%}\right)$ selection level.

\section{KEYWORDS: juvenile and trash excluder devices, mini trawl, bar, escaping ratio, selectivity}

\section{PENDAHULUAN}

Dalam rangka menemukan alat tangkap pengganti trawl, pemerintah melakukan upaya penelitian dan pengembangan alat tangkap tradisional seperti cantrang, arad, lampara dasar, dan dogol (danish seine) yang efektif namun tetap berkarakter selektif dan ramah lingkungan. Hasil penelitian dan pengembangan menunjukkan bahwa efektivitas dan produktivitas alat tangkap traw/ sampai dengan saat ini belum tertandingi oleh jenis alat tangkap lain. Didorong oleh kebutuhan pangan yang semakin meningkat dan desakan kebutuhan ekonomi, banyak nelayan mengembangkan dan memodifikasi alat tangkap cantrang dan dogol sehingga menyerupai trawl baik perlengkapan, cara operasi maupun efektivitas. Alat tangkap tersebut di wilayah pantai utara Jawa dikenal dengan nama cothok. Berdasarkan pada Keputusan Presiden No.39 tahun 1980, cothok yang beroperasi di Laut Jawa bersifat illegalkarena sebenarnya traw/mini.

Alat tangkap trawl dan sejenis dioperasikan dengan cara ditarik dengan kecepatan dan waktu tertentu di sepanjang dasar perairan untuk menangkap ikan-ikan dasar (FAO, 1995). Selama ini pemahaman mengenai traw/di Indonesia selalu berkonotasi sebagai alat tangkap udang, karena sasaran utama tangkapan adalah udang. Namun, alat tangkap seperti pukat ikan (fish net) maupun cothok (modifikasi dari arad) yang berprinsip sebagai alat tangkap trawl dasar tetap berkembang keberadaannya, karena alat tangkap tersebut ditujukan untuk menangkap ikan. Walaupun antara trawl, fish net, maupun cothok merupakan 1 jenis alat tangkap yang rendah tingkat selektivitas, namun demikian belum ada batasan yang jelas di 
lapangan penggunaan alat tangkap fish net dan cothok antara boleh atau tidak penggunaan alat tangkap tersebut.

Selain menangkap ikan berukuran besar yang telah dewasa dan mempunyai nilai ekonomis, alat tangkap fish net maupun cothok juga menangkap ikan muda yuwana (juvenile) dan rucah (trash fish) yang bernilai ekonomis rendah. Juvenile dan trash fish seperti ubur-ubur, bintang laut, dan kekerangan yang ikut tertangkap fish net dibuang kembali ke laut dalam keadaan mati dan diistilahkan sebagai discards (buangan) (Pascoe, 1997). Adapun juvenile dan trash fish yang tertangkap cothok di Laut Jawa tetap dimanfaatkan. Buangan dapat berdampak buruk terhadap sumber daya dan lingkungan. Tertangkap juvenile berpengaruh pada penurunan sumber daya ikan secara cepat, karena belum sempat dewasa dan bertelur serta beranak untuk kepentingan recruitment.

Menyikapi fenomena di atas, Balai Riset Perikanan Laut melakukan uji coba alat pereduksi ikan muda dan rucah pada alat traw/ mini. Alat pereduksi ikan muda dan rucah yang diuji coba merupakan hasil temuan peneliti SEAFDEC-Thailand yang telah dimodifikasi dan disesuaikan dengan alat tangkap yang dioperasikan di Indonesia. Alat pereduksi ikan muda dan rucah tersebut disebut juvenile and trash excluder devices. Tulisan ini menyajikan informasi tentang teknologi status alat tangkap traw/mini dan selektivitas kisi-kisi juvenile and trash excluder devices yang dipasang pada traw/mini.

\section{BAHAN DAN METODE}

\section{Bahan Penelitian}

Penelitian dilakukan pada tahun 2005 di perairan utara Jawa (Gambar 1) yang merupakan basis perikanan tangkap meliputi Tegal, Pekalongan, dan Semarang. Data dan informasi terkait dengan aspek selektivitas alat tangkap traw/mini diperoleh melalui uji coba pengoperasian traw/ mini yang dilengkapi dengan alat pereduksi ikan muda dan ikan rucah yang disebut juvenile and trash excluder devices. Juvenile and trash excluder devices dipasang pada bagian antara badan dan kantong jaring (Gambar 2).

Kegiatan uji coba dilakukan dengan menggunakan kapal berdimensi panjang (LoA) $23 \mathrm{~m}$, lebar (B) $5 \mathrm{~m}$, dan dalam (D) 1,2 m atau $64 \mathrm{GT}$, dengan mesin penggerak 360 HP. Kapal dilengkapi dengan traw/mini dengan ukuran tali ris atas (head rope) $21 \mathrm{~m}$, tali ris bawah (ground rope) $24 \mathrm{~m}$, ukuran mata jaring bagian kantong 1,5 inci.
Pada uji coba ini digunakan 3 macam perlakuan. Perlakuan pertama, juvenile and trash excluder devices dengan lebar kisi-kisi $10 \mathrm{~mm}$, ke-2 17,5 mm, dan ke-3 25,4 mm. Ketiga ukuran kisi-kisi juvenile and trash excluder devices dipasang pada sebuah mini trawl dan dioperasikan secara bergantian. Keseluruhan pengoperasian (70 kali), masing-masing ukuran kisi-kisi juvenile and trash excluder devices mendapat kesempatan uji coba sebagai berikut kisikisi 10,0 mm 20 kali, kisi-kisi 17,5 mm 27 kali, dan kisi-kisi 25,5 mm 23 kali ulangan. Masing-masing hasil tangkapan, baik yang masuk ke dalam codend maupun cover net ditimbang secara total dan dilakukan pengambilan contoh untuk selanjutnya diidentifikasi jenis, serta diukur panjang cagak (fork length). Identifikasi jenis ikan mengacu pada referensi Fischer \& Whitehead (1974).

\section{Analisis Data}

Tingkat kelolosan ikan yang tertangkap traw/mini yang dilengkapi juvenile and trash excluder devices dihitung dengan menggunakan formula:

Tingkat Kelolosan $(\%)=(\mathrm{W}$ cover netx100)/(W codend $+\mathrm{W}$ cover net)

di mana:

W cover net = bobot tangkapan $(\mathrm{kg})$ yang keluar (lolos) melalui juvenile and trash excluder devices dan tertampung dalam cover net

$W$ codend = bobot tangkapan $(\mathrm{kg})$ yang masuk ke kantong jaring traw/mini

Model yang secara langsung dan digunakan untuk mengestimasi selektivitas alat tangkap yang diuji coba dengan cara membandingkan ukuran panjang ikan (L) yang tertahan (masuk kantong jaring codend) dan yang lolos melalui kisi-kisi juvenile and trash excluder devices (tertampung di cover net). Kurva selektivitas traw/mini dengan juvenile and trash excluder devices didekati dengan model logistik (logistic curve) dihitung dengan menggunakan rumus sebagai berikut (Sparre \& Venema, 1999):

$$
S(l)=\frac{1}{\left[\left(1+\exp \left(\alpha^{*} l+\beta\right)\right]\right.}
$$

di mana:

á dan â = parameter-parameter dari model logistik dihitung melalui pendekatan maximum likelihood method (Tokai, 1997) 
= fungsi dari selektivitas juvenile and trash excluder devices terhadap panjang ikan

Untuk menentukan kemiringan dari kurva selektivitas (selection span) dihitung dengan rumus:
$\mathrm{SR}=-2 \ln (3) / a ́$

Data yang digunakan dalam analisis kurva selektivitas ini panjang cagak (fork length) ikan pepetek (Leiognathus spp.), kuniran (Upeneus sulphureus), beloso (Saurida undosquamis), dan kurisi (Nemipterus spp.).

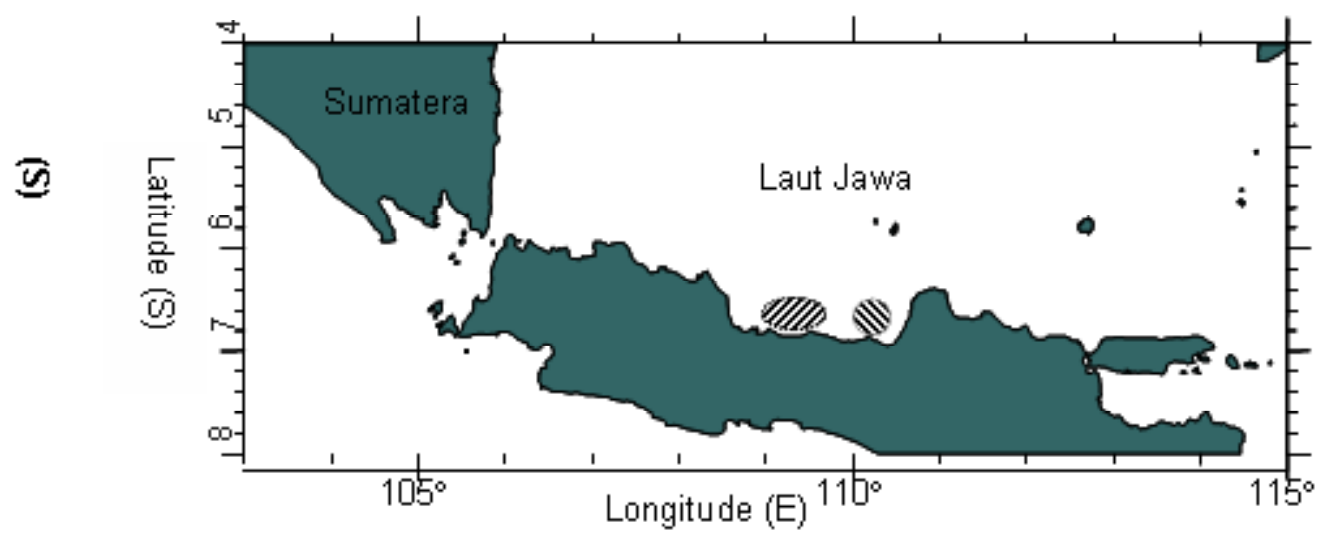

Lokasi penangkapan : Ulm Tegal dan Pekalongan, Semarang

Gambar 1. Peta lokasi penelitian juvenile and trash excluder devices.

Figure 1. Location map of juvenile and trash excluder devices experiment.
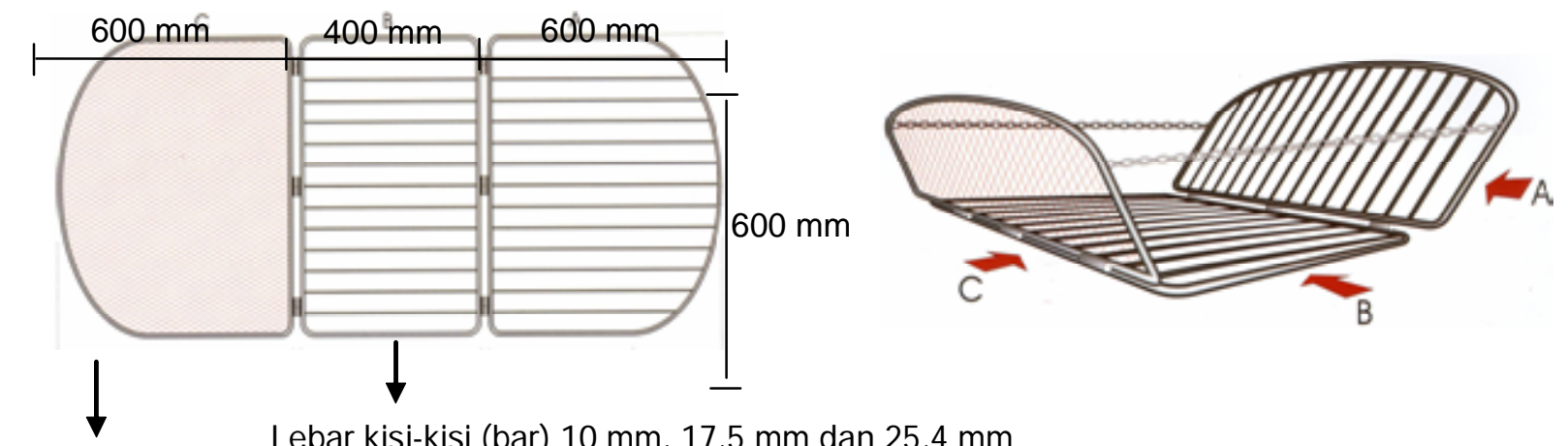

Besi beton

Lebar kisi-kisi (bar) $10 \mathrm{~mm}, 17,5 \mathrm{~mm}$ dan 25,4 mm

dia. $10 \mathrm{~mm}$

Besi beton dia. $6 \mathrm{~mm}$
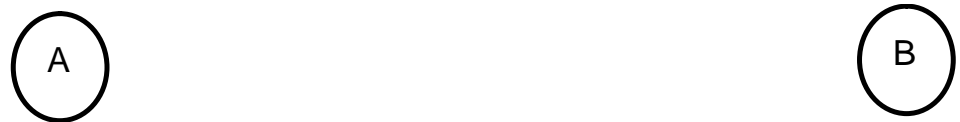

Gambar 2. A-B disain dan konstruksi juvenile and trash excluder devices yang di uji coba.

Figure 2. Design and construction of experimental juvenile and trash excluder devices.

\section{HASIL DAN BAHASAN}

Dalam rangka mengurangi dampak lingkungan yang diakibatkan oleh pengoperasian berbagai jaring traw/mini tersebut di atas, maka dilakukan penelitian untuk mengurangi tertangkap ikan muda dan rucah melalui uji coba juvenile and trash fish excluder devices yang dipasang pada alat tangkap traw/mini.

\section{Jumlah Hasil Tangkapan}

Tabel 1 menunjukkan persentase ikan hasil tangkapan yang berada pada kantong (codend) trawl mini dan yang berada pada cover net juvenile and trash fish excluder devices. Selama uji coba juvenile and trash fish excluder devices pada bulan September dan Oktober diperoleh bahwa pada kisi-kisi juvenile and trash fish excluder devices $17,5 \mathrm{~mm}$, persentase 
ikan yang berada di cover net jauh lebih banyak dibandingkan dengan ikan yang masuk kantong (codend) traw/mini. Secara umum, bahwa dari hasil uji coba juvenile and trash fish excluder devices pada bulan September, Oktober, dan Desember 2005 dibuktikan ke-3 ukuran kisi-kisi juvenile and trash fish excluder devices yakni kisi-kisi 10,0; 17,5; dan 25,4 mm dapat meloloskan ikan-ikan dengan ukuran Lc $<$ Lc ikan-ikan yang masuk kantong jaring traw/mini.

Tabel 1. Jumlah hasil tangkapan (kg per jam) di kantong dan di cover net pada uji coba traw/ mini yang dilengkapai juvenile and trash fish excluder devices bulan September, Oktober, dan Desember 2005

Table 1. The catch rate ( $\mathrm{kg}$ per hour) in codend and cover net of mini trawl equipped with juvenile and trash fish excluder devices on September, October, and December 2005

\begin{tabular}{|c|c|c|c|c|c|c|}
\hline \multirow{2}{*}{$\begin{array}{l}\text { Bulan/ } \\
\text { Month }\end{array}$} & \multirow{2}{*}{$\begin{array}{c}\text { Kisi-kisi } \\
\text { JTEDs/Space } \\
\text { bar JTEDs }\end{array}$} & \multirow{2}{*}{$\begin{array}{c}\text { Jumlah } \\
\text { tawur/Total } \\
\text { setting }\end{array}$} & \multicolumn{4}{|c|}{ Rata-rata tangkapan/Catch average (kg per jam) } \\
\hline & & & $\begin{array}{c}\text { Kantong/ } \\
\text { Codend }\end{array}$ & $\%$ & Cover & $\%$ \\
\hline \multirow{3}{*}{ September 2005} & $10,0 \mathrm{~mm}$ & 7 & 7,64 & 59,8 & 5,03 & 40,2 \\
\hline & $17,5 \mathrm{~mm}$ & 7 & 4,32 & 36,5 & 7,59 & 63,5 \\
\hline & $25,4 \mathrm{~mm}$ & 7 & 5,27 & 47,1 & 6,28 & 52,9 \\
\hline \multirow{3}{*}{ Oktober 2005} & $10,0 \mathrm{~mm}$ & 5 & 16,42 & 97,6 & 0,30 & 2,4 \\
\hline & $17,5 \mathrm{~mm}$ & 8 & 9,95 & 55,1 & 2,38 & 32,5 \\
\hline & $25,4 \mathrm{~mm}$ & 7 & 12,29 & 69,4 & 6,48 & 31,3 \\
\hline \multirow{3}{*}{ Desember 2005} & $10,0 \mathrm{~mm}$ & 8 & 148,90 & 95,3 & 4,65 & 4,7 \\
\hline & $17,5 \mathrm{~mm}$ & 12 & 61,03 & 90,5 & 5,79 & 9,5 \\
\hline & $25,4 \mathrm{~mm}$ & 9 & 86,08 & 79,9 & 9,95 & 20,1 \\
\hline
\end{tabular}

\section{Jenis Ikan}

Selama uji coba traw/mini pada bulan September, jenis ikan hasil tangkapan yang berhasil diidentifikasi 72 spesies (46 famili) meliputi ikan, udang, kepiting, cumi-cumi, sotong, dan biota invertebrata lain. Jumlah individu terbanyak dari jenis ikan pepetek (Leiognathus splenden, Leiognathidae) mencapai $192,5 \mathrm{~kg}$ $(61,78 \%)$. Urutan berikut ikan tiga waja (Johnius dussumieri, Sciaenidae) 19,5 kg (6,25\%) dan ikanikan jenis beloso (Saurida undosquamis, Sinodontidae) $14,0 \mathrm{~kg}(4,51 \%)$.

Jenis ikan hasil tangkapan traw/ mini selama uji coba pada bulan Oktober teridentifikasi 47 famili meliputi udang, kepiting, cumi-cumi, sotong, dan biota invertebrata lain. Jumlah individu terbanyak jenis ikan beloso (Saurida undosquamis, Sinodontidae) mencapai 19,41 kg (19,41\%). Urutan berikut ikan pepetek (Leiognathus splenden, Leiognathidae) 39,24 $\mathrm{kg}(15,51 \%)$ dan kurisi (Nemipterus spp., Nemipteridae) $31,03 \mathrm{~kg}(12,27 \%)$.

Pada uji coba bulan Desember 2005 diperoleh ikan yang teridentifikasi 63 famili meliputi ikan, udang, kepiting, cumi-cumi, sotong, dan biota invertebrata lain. Jumlah individu terbanyak dari jenis ikan pepetek (Leiognathus splenden, Leiognathidae) $497,11 \mathrm{~kg}$ (28,33\%). Berikut ikan beloso (Saurida undosquamis, Sinodontidae) $147,57 \mathrm{~kg}(8,41 \%)$. Jenis ikan pepetek
(Leiognathus splenden, Leiognathidae) dan beloso (Saurida undosquamis, Sinodontidae) yang mendominansi hasil tangkapan di Laut Jawa memberikan informasi yang sama dibanding dengan spesies hasil tangkapan traw/ di Selat Malaka pada bulan Agustus 2003 (Hufiadi \& Nurdin 2006) dan hasil tangkapan traw/di Laut Jawa pada bulan Oktober 2002 (Pujiyati et al., 2007) menunjukkan bahwa spesies ini tersebar dan dapat beradaptasi di seluruh perairan.

\section{Ukuran Ikan}

Hasil pengukuran terhadap panjang, tebal, dan tinggi badan ikan contoh yang dominan tertangkap dapat dilihat pada Tabel 2. Ukuran ikan dibedakan antara ikan yang masuk kantong jaring trawl mini (codend) dan jaring pembungkus juvenile and trash fish excluder devices (cover net) dari masing-masing ukuran kisi-kisi ukuran 10,0; 17,5; dan 25,4 mm. Berdasarkan pada Tabel 2, dapat disimpulkan bahwa rata-rata ukuran ikan contoh dari ke-3 perlakuan kisikisi juvenile and trash fish excluder devices, yang lolos atau masuk cover net cenderung berukuran lebih kecil dibandingkan dengan rata-rata ukuran ikan yang masuk kantong (codend). Demikian pula, berdasarkan pada ukuran kisi-kisi juvenile and trash fish excluder devices, diperoleh bahwa semakin besar ukuran kisikisi, rata-rata ukuran contoh ikan yang lolos atau tertampung pada cover net cenderung berukuran semakin besar sesuai dengan ukuran kisi-kisi. 
Tabel2. Rata-rata ukuran contoh ikan yang masuk juvenile and trash fish excluder devices (cover net) dan masuk kantong trawl (codend) dengan 3 macam ukuran kisi-kisi juvenile and trash fish excluder devices 10,0; 17,5 ; dan 25,4 mm

Table 2. The length average of fish sample in juvenile and trash fish excluder devices cover net and codend by juvenile and trash fish excluder devices 10.0; 17.5; and $25.4 \mathrm{~mm}$ of the space bar

\begin{tabular}{|c|c|c|c|c|c|c|c|c|c|c|}
\hline \multirow[b]{2}{*}{ No. } & \multirow{2}{*}{$\begin{array}{c}\text { Perlakuan/ } \\
\text { Treatment }\end{array}$} & \multirow{2}{*}{$\begin{array}{l}\text { Jenis/ } \\
\text { Species }\end{array}$} & \multicolumn{4}{|c|}{ JTEDs/Cover } & \multicolumn{4}{|c|}{ Kantong trawl/Codend } \\
\hline & & & FL & $\begin{array}{c}\text { Tinggi/ } \\
\text { High }\end{array}$ & $\begin{array}{l}\text { Tebal/ } \\
\text { Width }\end{array}$ & $\mathbf{n}$ & FL & $\begin{array}{c}\text { Tinggi/ } \\
\text { High }\end{array}$ & $\begin{array}{l}\text { Tebal/ } \\
\text { Width }\end{array}$ & $\mathbf{n}$ \\
\hline \multirow{3}{*}{1.} & & $\begin{array}{l}\text { Saurida } \\
\text { longimanus }\end{array}$ & 10,0 & 1,0 & 0,9 & 211 & 12,9 & 1,4 & 1,3 & 212 \\
\hline & Kisi-kisi JTEDs & Upeneus spp. & 7,0 & 1,2 & 0,9 & 132 & 9,9 & 2,3 & 1,2 & 150 \\
\hline & $10,0 \mathrm{~mm}$ & $\begin{array}{l}\text { Leiognathus } \\
\text { splenden }\end{array}$ & 6,2 & 2,9 & 0,8 & 126 & 9,5 & 4,7 & 1,3 & 85 \\
\hline \multirow{5}{*}{2.} & & $\begin{array}{l}\text { Nemipterus } \\
\text { Japonicus }\end{array}$ & 6,3 & 1,6 & 0,8 & 120 & 13,2 & 2,6 & 1,5 & 193 \\
\hline & & $\begin{array}{l}\text { Saurida } \\
\text { longimanus }\end{array}$ & 12,4 & 1,1 & 1,1 & 201 & 18,0 & 1,9 & 1,5 & 196 \\
\hline & Kisi-kisi JTEDs & Upeneus spp. & 9,4 & 2,2 & 1,2 & 105 & 11,6 & 2,9 & 1,6 & 168 \\
\hline & $17,5 \mathrm{~mm}$ & $\begin{array}{l}\text { Leiognathus } \\
\text { splenden }\end{array}$ & 7,1 & 3,0 & 1,6 & 85 & 10,7 & 5,1 & 1,5 & 58 \\
\hline & & $\begin{array}{l}\text { Nemipterus } \\
\text { Japonicus }\end{array}$ & & & & & 12,4 & 4,4 & 1,8 & 7 \\
\hline \multirow{5}{*}{3.} & & $\begin{array}{l}\text { Saurida } \\
\text { pectoralis }\end{array}$ & & & & & 16,9 & 3,08 & 1,9 & 16 \\
\hline & & $\begin{array}{l}\text { Saurida } \\
\text { longimanus }\end{array}$ & 13,2 & 1,3 & 1,2 & 167 & 17,3 & 1,9 & 1,7 & 132 \\
\hline & Kisi-kisi JTEDs & Upeneus spp. & 10,8 & 2,6 & 1,4 & 206 & 11,5 & 2,9 & 1,5 & 180 \\
\hline & $25,4 \mathrm{~mm}$ & $\begin{array}{l}\text { Leiognathus } \\
\text { splenden }\end{array}$ & 8,8 & 4,4 & 1,2 & 232 & 10,8 & 5,6 & 1,4 & 98 \\
\hline & & $\begin{array}{l}\text { Nemipterus } \\
\text { Japonicus }\end{array}$ & 13,9 & 3,9 & 1,8 & 125,0 & 16,6 & 4,9 & 2,1 & 80 \\
\hline
\end{tabular}

\section{Selektivitas Juvenile and Trash Fish Excluder Devices}

Selekivitas alat tangkap adalah kemampuan menentukan sasaran dalam menangkap ikan menurut jenis, kelamin, dan ukuran atau kombinasi ke-3 selama proses penangkapan dan memungkinkan semua hasil tangkapan non sasaran diloloskan tanpa cidera (FAO, 1995). Selain itu, dikatakan juga bahwa selektivitas alat tangkap adalah fungsi alat tangkap untuk menangkap ikan yang terbatas pada jenis dan ukuran ikan tertentu pada suatu populasi yang ditemui di daerah penangkapan atau status populasi (Arimoto, 1999; Ferno \& Olsen, 1994). Selektivitas alat tangkap ikan dalam arti mekanis (mechanical selectivity) terdiri atas 2 komponen, yaitu selektivitas terhadap jenis (species) dan selektivitas terhadap ukuran (size) yang pada umumnya diwakili oleh ukuran panjang $(L)$.

Kurva selektivitas traw/mini yang dipasangi juvenile and trash fish excluder devices terhadap ikan petek (Leiognathus bindus) disajikan pada Gambar 4. Hasil analisis selektivitas menunjukkan panjang cagak (fork length) ikan pepetek (Leiognathus splenden) pada tingkat seleksi $50 \%\left(\mathrm{FL}_{50 \%}\right)$ untuk kisi-kisi 10,0 mm $71,63 \mathrm{~mm}$, kisi-kisi 17,5 mm 94,75, dan kisi-kisi 25,4 $\mathrm{mm} 88,12 \mathrm{~mm}$. Berdasarkan pada nilai tersebut, kisi- kisi $17,5 \mathrm{~mm}$ dapat meloloskan ikan petek (Leiognathus bindus) dengan fork length yang lebih besar dibandingkan dengan kisi-kisi 10,0 dan kisikisi $25,4 \mathrm{~mm}$ pada tingkat selektivitas $50 \%$. Sementara itu, untuk kisi-kisi-kisi 25,4 mm dapat meloloskan ikan petek (Leiognathus bindus) dengan ukuran fork length sedikit lebih besar dibandingkan kisi-kisi 10,0 mm. Nilai kemiringan kurva selektivitas (selection span) untuk kisi-kisi 10,0; 17,5; dan kisikisi 25,4 mm berurutan masing-masing 12,27; 5,18; dan 30,31 . Berdasarkan pada nilai tersebut menunjukkan bahwa kisi-kisi 25,4 mm memiliki kemiringan kurva selektivitas yang lebih besar atau lebih landai dibandingkan kisi-kisi 10,0 dan 17,5 mm. Kemiringan kurva sangat menentukan kisaran ukuran ikan yang terseleksi (range of selection) pada tingkat selektivitas $50 \%$ semakin besar nilai kemiringan kurva, maka kisaran ukuran ikan yang terseleksi semakin lebar (Purbayanto et al., 2006).

Gambar 5 menunjukkan, bahwa panjang cagak (fork length) ikan kuniran (Upeneus sulphureus) pada tingkat seleksi $50 \%\left(\mathrm{FL}_{50 \%}\right)$ untuk kisi-kisi 10,0 mm $84,99 \mathrm{~mm}$, kisi-kisi 17,5 mm 105,78, dan kisi-kisi 25,4 $\mathrm{mm} 90,54 \mathrm{~mm}$. Berdasarkan pada nilai tersebut, kisikisi $17,5 \mathrm{~mm}$ dapat meloloskan ikan-ikan kuniran (Upeneus sulphureus) dengan fork length yang lebih 
besar dibandingkan dengan kisi-kisi 10,0 dan kisikisi $25,4 \mathrm{~mm}$ pada tingkat selektivitas $50 \%$. Sementara itu, untuk kisi-kisi-kisi 25,4 mm dapat meloloskan ikan kuniran (Upeneus sulphureus) dengan ukuran fork length sedikit lebih besar dibandingkan kisi-kisi 10,0 mm. Nilai kemiringan kurva selektivitas (selection span) untuk kisi-kisi 10,0; 17,5; dan 25,4 mm berurutan 20,41; 37,39; dan 82,40.
Berdasarkan pada nilai tersebut menunjukkan bahwa kisi-kisi 25,4 mm memiliki kemiringan kurva selektivitas yang lebih besar atau lebih landai dibandingkan kisi-kisi 10,0 dan 17,5 mm. Hal ini menunjukkan bahwa, kisi-kisi 25,4 memperoleh kisaran ukuran ikan yang terseleksi lebih lebar dibandingkan dengan kisi-kisi 10,0 dan 17,5 mm pada tingkat selektivitas $50 \%$.

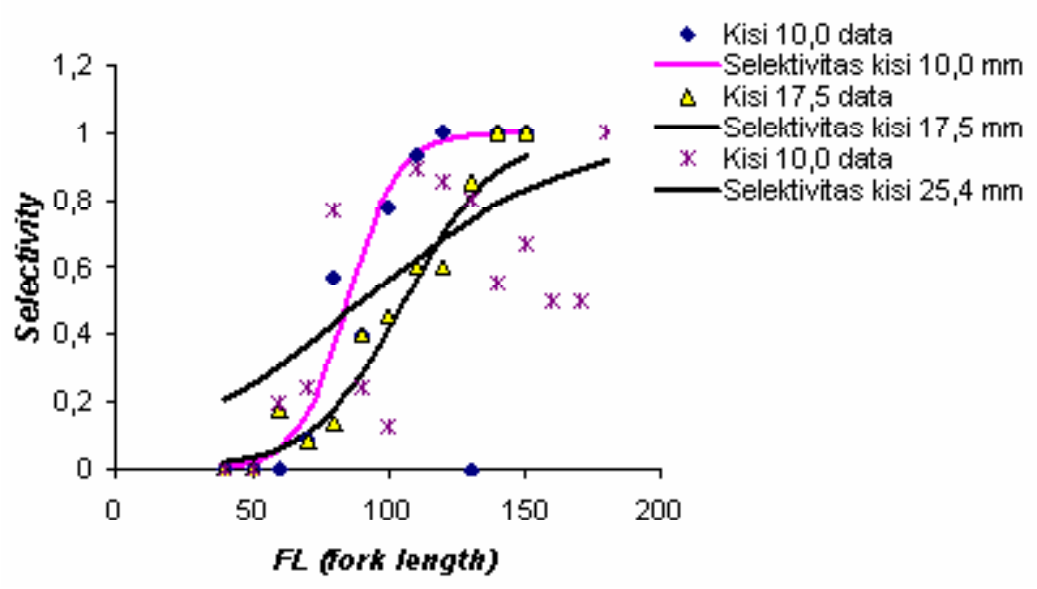

Gambar 5. Kurva selektivitas traw/mini yang dilengkapi juvenile and trash fish excluder devices terhadap ikan kuniran (Upeneus sulphureus).

Figure 5. Mini trawl net selectivitiy curve of kuniran(Upeneus sulphureus).

Kurva selektivitas mini trawlyang dipasangi juvenile and trash fish excluder devices terhadap ikan beloso (Saurida undosquamis) disajikan pada Gambar 6. Hasil analisis selektivitas menunjukkan panjang cagak (fork length) ikan beloso (Saurida undosquamis) pada tingkat seleksi $50 \%\left(\mathrm{FL}_{50 \%}\right)$ untuk kisi-kisi 10,0 mm 100,66 mm; kisi-kisi 17,5 mm 168,34 $\mathrm{mm}$, dan kisi-kisi 25,4 mm 118,91 mm. Berdasarkan pada nilai tersebut, kisi-kisi $17,5 \mathrm{~mm}$ dapat meloloskan ikan-ikan beloso (Saurida undosquamis) dengan fork length yang lebih besar dibandingkan dengan kisi-kisi 10,0 dan $25,4 \mathrm{~mm}$ pada tingkat selektivitas $50 \%$. Sementara itu, untuk kisi-kisi 25,4 $\mathrm{mm}$ dapat meloloskan ikan beloso (Saurida undosquamis) dengan ukuran fork length sedikit lebih besar dibandingkan kisi-kisi 10,0 mm. Nilai kemiringan kurva selektivitas (selection span) untuk kisi-kisi 10,0; 17,5; dan 25,4 mm berurutan 52,07; 69,84; dan 91,31. Berdasarkan pada nilai tersebut, kisi-kisi 25,4 mm memiliki kemiringan kurva selektivitas yang lebih besar atau lebih landai dibandingkan kisi-kisi 10,0 dan 17,5 $\mathrm{mm}$. Nilai kemiringan kurva selektivitas terhadap ikan beloso (Saurida undosquamis) sama seperti hal yang ditunjukkan terhadap ikan pepetek (Leiognathus splenden) dan kuniran (Upeneus sulphureus) bahwa kisi-kisi 25,4 memperoleh kisaran ukuran ikan yang terseleksi lebih lebar dibandingkan dengan kisi-kisi 10,0 dan $17,5 \mathrm{~mm}$ pada tingkat selektivitas $50 \%$.
Gambar 7, menunjukkan kurva selektivitas mini trawlyang dipasangi juvenile and trash fish excluder devices terhadap ikan kurisi (Nemipterus spp.). Panjang cagak (fork length) ikan kurisi (Nemipterus spp.) pada tingkat seleksi $50 \%\left(\mathrm{FL}_{50 \%}\right)$ untuk kisi-kisi $10,0 \mathrm{~mm} \mathrm{59,56} \mathrm{mm}$, kisi-kisi 17,5 mm 96,55, dan kisi-kisi 25,4 mm 95,41 mm. Berdasarkan pada nilai tersebut, kisi-kisi 17,5 mm dapat meloloskan ikanikan kurisi (Nemipterus spp.) dengan fork lengthyang lebih besar dibandingkan dengan kisi-kisi 10,0 dan $25,4 \mathrm{~mm}$ pada tingkat selektivitas $50 \%$. Sementara itu, untuk kisi-kisi 25,4 mm dapat meloloskan ikan kurisi (Nemipterus spp.) dengan ukuran fork length lebih besar dibandingkan kisi-kisi 10,0 mm. Nilai kemiringan kurva selektivitas (selection span) untuk kisi-kisi 10,0; 17,5; dan 25,4 mm berurutan 23,77; 71,92; dan 42,49. Berdasarkan pada nilai tersebut menunjukkan bahwa kisi-kisi 17,5 mm memiliki kemiringan kurva selektivitas yang lebih besar atau lebih landai dibandingkan kisi-kisi 10,0 dan 25,4 mm.

Berdasarkan pada hasil analisis selektivitas mini traw/yang dipasangi juvenile and trash fish excluder devices terhadap 4 jenis ikan yaitu ikan petek (Leiognathus bindus), kuniran (Upeneus sulphureus), beloso (Saurida undosquamis), dan kurisi (Nemipetrus spp.) diperoleh bahwa panjang cagak (fork length) pada tingkat seleksi 50\% $\left(F L_{50 \%}\right)$ untuk kisi-kisi 17,5 $\mathrm{mm}$ dapat meloloskan ikan-ikan tersebut dengan 
ukuran fork length yang lebih besar dibandingkan dengan kisi-kisi 10,0 dan $25,4 \mathrm{~mm}$ pada tingkat selektivitas $50 \%$. Sementara itu, untuk kisi-kisi 25,4 $\mathrm{mm}$ dapat meloloskan ikan beloso (Saurida undosquamis) dengan ukuran fork length sedikit lebih besar dibandingkan kisi-kisi 10,0 mm. Berdasarkan pada nilai yang dihasilkan, ke-3 perlakuan ukuran kisikisi $(10,0 ; 17,5$; dan 25,4 mm) untuk meloloskan ikanikan muda atau rucah paling efektif pada ukuran kisi- kisi $17,5 \mathrm{~mm}$. Meskipun terdapat kecenderungan bahwa nilai kemiringan kurva selektivitas semakin besar ukuran kisi-kisi juvenile and trash fish excluder devices cenderung semakin landai. Sebagaimana dikatakan oleh Purbayanto et al. (2006), bahwa performa selektivitas ukuran celah pelolosan dapat dinilai dari kemiringan kurva (selection span) dan tingkat seleksi pada $\mathrm{L}_{50 \%}\left(\mathrm{FL}_{50 \%}\right)$.

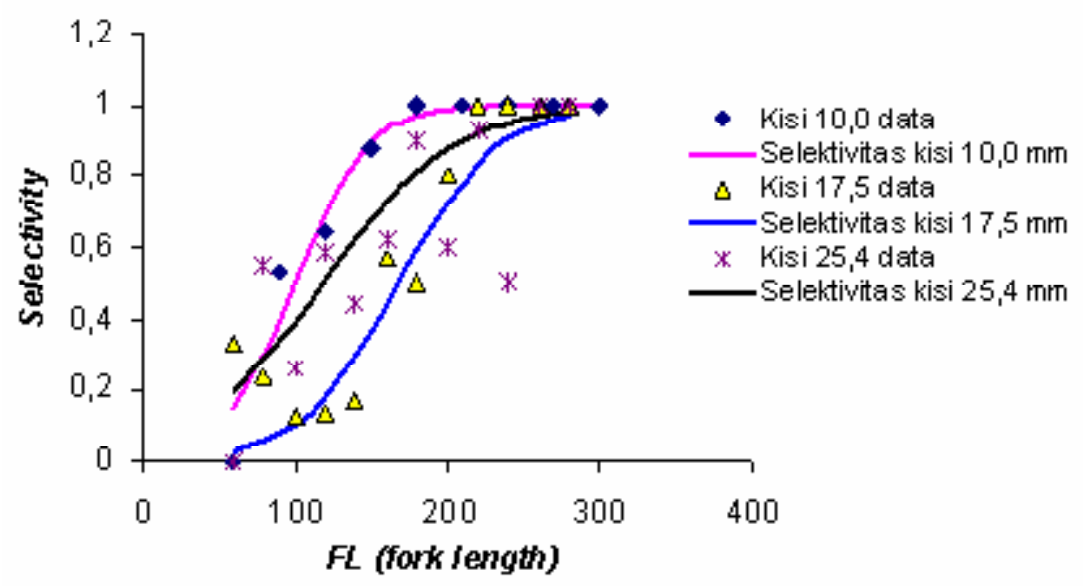

Gambar 6. Kurva selektivitas traw/mini yang dilengkapi juvenile and trash fish excluder devices terhadap ikan beloso (Saurida longimanus).

Figure 6. Mini trawl net selectivitiy curve of beloso (Saurida longimanus).

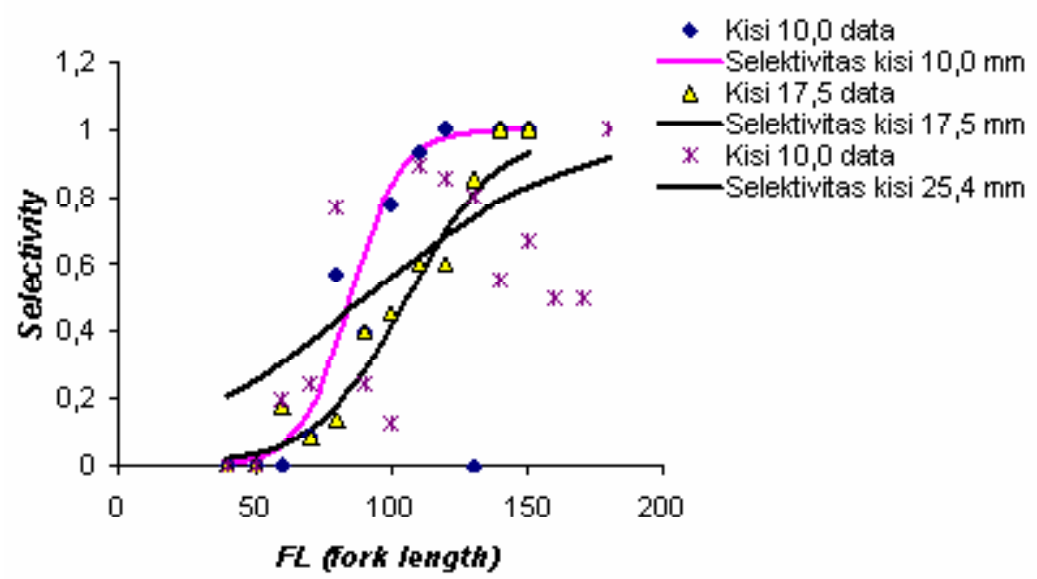

Gambar 7. Kurva selektivitas traw/mini yang dilengkapi juvenile and trash fish excluder devices terhadap ikan kurisi (Nemipetrus spp.).

Figure 7. Mini trawl net selectivitiy curve of kurisi (Nemipetrus spp.).

Berdasarkan pada hasil analisis nilai kemiringan kurva selektivitas (selection span) terhadap jenis ikan petek (Leiognathus bindus), kuniran (Upeneus sulphureus), dan beloso (Saurida undosquamis), diperoleh kisi-kisi 25,4 mm memiliki kemiringan kurva selektivitas yang lebih besar atau cenderung lebih landai dibandingkan kisi-kisi 10,0 dan $17,5 \mathrm{~mm}$ pada tingkat selektivitas $50 \%$. Sementara itu, nilai kemiringan kurva yang ditunjukkan terhadap jenis ikan kurisi (Nemipetrus spp.) pada tingkat selektivitas yang sama bahwa kisi-kisi 17,5 mm memiliki kemiringan kurva selektivitas yang lebih besar atau cenderung lebih landai dibandingkan kisi-kisi 10,0 dan 25,4 mm. Artinya bahwa semakin besar nilai kemiringan kurva, maka kisaran ukuran ikan yang terseleksi semakin lebar.

Beberapa ukuran length of first capture jenis ikan yang dominan tertangkap jaring trawl di Laut Jawa dari hasil penelitian Dwiponggo et al. (1986) antara 
lain ikan beloso (Saurida longimanus) berukuran Lc 10,35 cm, petek (Leiognathus splenden) Lc 6,23 cm, kuniran (Upeneus spp.) Lc 9,72 cm, dan kurisi (Nemipterus spp.) Lc 10,40 cm. Ukuran length of first capture ikan dari hasil penelitian Dwiponggo et al. (1986) tersebut dibandingkan dengan ukuran length of first capture ikan yang masuk kantong (codend) pada traw/mini yang dipasang juvenile and trash fish excluder devices dengan kisi-kisi 17,5 mm berukuran length of first capture lebih kecil, sedangkan dibandingkan dengan ukuran length of first capture ikan yang masuk kantong (codend) pada trawlyang dipasang juvenile and trash fish excluder devices dengan kisi-kisi 10,0 dan 25,4 mm pada ikan kurisi (Nemipterus spp.) berukuran length of first capture lebih besar. Dengan demikian, menunjukkan pemasangan juvenile and trash fish excluder devices untuk kisi-kisi 17,5 mm selain lebih efektif juga berarti dapat meloloskan ikan-ikan kecil yang berukuran length of first capture di bawah ukuran ikan pertama kali dapat ditangkap.

Dengan demikian, hasil penelitian ini menunjukkan bahwa pemasangan juvenile and trash fish excluder devices pada alat tangkap traw/berhasil meloloskan sebagian ikan-ikan yang berukuran lebih kecil dari yang tertangkap. Dengan harapan dapat menunda waktu penangkapan bagi ikan-ikan ukuran kecil atau muda (juvenile) sampai dengan dapat tumbuh besar dan dapat bertelur atau memijah. Kondisi ini berarti rekruitmen dapat berjalan dan over fishing di waktu mendatang dapat dihindari.

\section{KESIMPULAN}

1. Penggunaan juvenile and trash fish excluder devices pada mini traw/ukuran kisi-kisi 10,0; 17,5; dan 25,4 $\mathrm{mm}$ masing-masing meloloskan ikan berukuran kecil berkisar antara 2,42 sampai dengan $40,18 \%$, 9,47 sampai dengan $63,45 \%$, dan 4,65 sampai dengan $26,05 \%$ dari total ikan yang tertangkap.

2. Terdapat kecenderungan semakin lebar ukuran kisi-kisi juvenile and trash fish excluder devices, kisaran ukuran ikan yang terseleksi semakin lebar.

3. Kisi-kisi $17,5 \mathrm{~mm}$ dapat meloloskan ikan-ikan dengan ukuran fork length yang lebih besar dibandingkan dengan kisi-kisi 10,0 dan 25,4 mm pada tingkat selektivitas $50 \%$.

4. Ukuran kisi-kisi $17,5 \mathrm{~mm}$ memiliki tingkat kelolosan ikan-ikan muda atau rucah paling efektif dibandingkan kisi-kisi 10,0 dan 25,4 mm.

\section{PERSANTUNAN}

Kegiatan dari hasil riset selektivitas unit penangkapan pukat dasar (bottom seine net) di utara Jawa, T.A 2005 dan 2006, di Balai Riset Perikanan Laut.

\section{DAFTAR PUSTAKA}

Arimoto, T. 1999. Fish behaviour for improving fish capture technology. Tokyo University of Fisheries, Japan. 55 p.

Dwiponggo, A., T. Hariati, S. Banon, M. L. Palomares, \& D. Pauly. 1986. Growth, mortality, and recruitment of commercially important fishes and penaeid shrimps in Indonesian waters. RIMF and ICLARM. 91 p.

FAO. 1995. Code of conduct for responsible fisheries. FAO. Rome.

Ferno, A. \& S. Olsen. 1994. Marine fish behaviour in capture abundance estimation. Fishing News Book. London. p. 69-81.

Fischer,W. \& P. J. P. Witehead. 1974. FAO species identification sheet $\mathrm{s}$ for fishery purposes. Eastern Indian Ocean (Fishing Area 57) and Western Central Pacific (Fishing Area 71). Rome. FAO. 4 Vols. pag. var.

Hufiadi \& E. Nurdin. 2006. Laju tangkap dan kepadatan stok ikan demersal di perairan sekitar Pulau Berhala, Selat Malaka. Seminar Nasional Perikanan Tangkap. Departemen Pemanfaatan Sumber Daya Perikanan. Fakultas Perikanan dan IImu Kelautan. Institut Pertanian Bogor. Bogor. p. 128-133.

Pascoe, S. 1997. Bycatch management and the economic of discarding. FAO Fisheries Technical Paper. FAO. Rome. 370. 1-27. 87-96.

Purbayanto, A., R. I. Wahyu, \& S. Tirta. 2006. Selektivitas bubu yang dilengkapi dengan celah pelolosan terhadap ikan kakap (Lutjanus sp. Bleeker). Gakuryoku. XII (1). 92-98.

Pujiyati, S., Wijopriono, Mahiswara, B. P. Pasribu, I. Jaya, \&. D. Manurung. 2007. Estimasi hambur balik dasar perairan dan sumber daya ikan demersal menggunakan metode hidroakustik. Jurnal Penelitian Perikanan Indonesia. Pusat Riset Perikanan Tangkap. Badan Riset Kelautan dan Perkanan. Vol.13 No.2. Jakarta. p.145-155. 
Sparre, P. \& S. C. Venema. 1999. Introduksi pengkajian stok ikan tropis. Organisasi Pangan dan Pertanian Perserikatan Bangsa-Bangsa. FAO. Pusat Penelitian dan Pengembangan Perikanan. Badan Penelitian dan Pengembangan Pertanian Jakarta. 438 hal.

Tokai, T. 1998. Trawl with separator Panel for bycatch reduction and evaluation methodology of the selective performance. Symposium on Marine Fisheries Beyond the Year 2000. Sustainable Utilization of Fisheries Resources. National Taiwan Ocean University. $7 \mathrm{p}$.

Tokai, T. 1997. Maximum likelihood parameter estimates of a mesh selectivity logistic model through SOLVER on MS-Excel. Bulletin Japanesse Society Fishery Oceanograhy. 61. 288298. 